\title{
Research on Ethnic Eco-ethics and Eco-civilization's Construction in Chinese Ethnic Regions
}

\author{
Jingfu Guo, Haijun Mao \& Yuwen Yang \\ School of Economy \& Management, Dalian Nationalities University \\ Dalian 116600, China \\ E-mail: drguo@dlnu.edu.cn
}

This paper is sponsored by the Social Science Planning Program of Education Ministry (08JA850002)

\begin{abstract}
Eco-civilization is the integral product of material achievement, spiritual achievement and regulations. It's the cultural $\&$ ethical manifestation of the harmonic coexistence of humans \& nature, balanced development, sustainable prosperity. The key ideology is the harmony and equality between nature and humans, the co-existence of multi-species and the re-production of resources. The nature ideology of integral harmony of the Chinese minority nations, and their ideology of equality of admiring life and the ideology of production of simple circulation are identical to the central ideology of eco-civilization. It reflects mankind's pursuit for a natural and harmonious ecology. And it plays a positive role in the construction of ecological civilization. To some extent the ecological ethics of the minorities is very important to protect the natural ecological environment, and promote the continuous and harmonic development of the ethnic regions. In this paper the method to construct the eco-civilization in Chinese ethnic regions are explained, such as the development of the eco-ethics of the minorities, and educate the sense of eco-citizen, perfection of the policies and regulations to protect the ecological environment of the ethnic regions.
\end{abstract}

Keywords: Ecological ethics, Ethnic regions, Eco-civilization, Circular economy

\section{Ecological civilization and the ecological situation in the ethnic regions}

Since the beginning of last century, industrial civilization brought a lot of issue as well as progress made in technology $\&$ material wealth. To a certain point, these issues are anti-human $\&$ anti-nature. The environment is only treated as resources, carrier \& receptor. The model of over consumption, high pollution caused the depletion of resources, pollution of the environment $\&$ the deterioration of ecology. While enjoying economical prosperity, mankind sacrifices hygiene, health, pleasant environmental conditions, \& peace of mind. People have to rethink about the consequences and try to find a new model of development for the sake of sustainable development for future generations. Science then mankind entered eco-civilization period. Eco-civilization coordinates social-economical development with the environment \& natural resources, establishes a new civilization based upon mutual benefit \& coordination between man $\&$ nature. It's a cultural \& ethical manifestation of harmonious coexistence, well-rounded development, and sustainable prosperity between human \& nature.

Eco-civilization has the following aspects: the first is the harmony and equality between man \& nature. Eco-civilization requires the culture value view-point of eco-system, humans regard nature protection as their inherent faith rather than humans-oriented. The second is production under the precondition of sustainable development. Obeying the principle that the ecological system is limited, elastic and unable to be predicted completely, the work of us, humans has to use natural resources in a way that's economical, synthetic and recyclable. An ecological industry system needs to be formed which becomes the main source of economical development. The third is consumption to satisfy one's own need without harming the environment. The life style of "living by no more than essential demand" is recommended, by which the pursuit of mankind is not materialism but to satisfy one's own need without damaging nature, to satisfy the need of this generation without harming the prospects of future generations. This ethics of peace and sharing is the code of harmonic coexistence and development between humans and nature, and within human society.

In our country, the habitats of the minorities are mostly located in the aboriginal and mountainous areas. From the 
northeast, northwest and southwest border areas make up most of the autonomy of minorities. Many of these places are; deserts, woodland and mountainous areas where the natural conditions are poor. Due to the historical, geological and social reasons, the ecological environment issue is especially remarkable, which becomes the key factor to restrain the development of the ethnic regions. The four major ecological fragile belts of our country (severe cold, deserts, infertile yellow soil and Karst) are the main distribution in the areas of minorities. In the process of industrialization, the ecological environment of minority areas tends to deteriorate severely with series of severe ecological crises, such as the over-use and destruction of the forests and wetlands, the deterioration of woodland, the lost of water and soil, drought and water shortage, flooding, desertification, extinction of native plant and animal species etc. (e.g. Table 1 as follows) Certain places fall into the malignant cycle of "poverty-destruction-poverty", which not only affects the existence and development of the people in the minority areas, but also generate environmental refugees and collision between races, affects the stability of the minority areas and the safety of the boundaries, which may also turns in to corresponding social risks.

The ethnic areas (five auto-autonomy regions and three provinces Yunnan, Guizhou and Qinghai etc. with more minority populations) are the boundary's green shield of the motherland, the treasure house of multi-ecological status with rich ecological ethics and culture, also have advantages of natural resources, the advantage of multi-ecological status, the advantage of culture and the organizational advantage of autonomy of the ethnic regions. Whether if the production is developed, the richness of life and the well development of ecology, the harmonious development of the economy with minority characteristics and the construction of ecological civilization is an important subject related to whether the idea of scientific development can be materialized in our country and to reach the goal to construct harmonious society.

\section{The conformability between the eco-ethics of ethnic minorities and the core value of the eco-civilization}

During the long-term process of interacting with nature ethnic minorities established their unique way of survival \& cultural ethics, formed their unique national customs and eco-ethics of protecting environment and wild animals.

\subsection{The nature view of overall harmony}

To treat nature with respect is the kind of harmonic model of handling the relationship between man and nature by ethnic minorities. It takes man \& nature as an inseparable entirety, maintains that nature is the basis of human life and eternal destiny, and that human \& nature must rely on each other, coexist in prosperity and develop in coordination. For example, people who are in belief of Shamanism in north China believe that humans should treat nature and all creatures with respect, live in harmony with all kinds of different organisms. This ecological idea no doubt regulates the behavior of ethnic minorities \& promotes environmental protection of nature and ecological harmony.

\subsection{The view of renewable production}

Since it's very hard to choose their ecological environment, ethnic minorities have to conduct production activities under realistic natural conditions, and their views on everyday living are evolved to adapt distinctively to the unique geographical environment. The existence of these concepts plays an important guidance role in waste reduction, green consumption, less impact on nature and wild animal protection. It also maintains local ecological balance, coordinates the harmonic fusion between man \& nature, and promotes practical natural way of living which restores nature to its original condition. For example, the nomadic way of constant migration for animal husbandry, and the nomadic way of rotation of grassland and pasture to reduce pressure on human activity, to ensure that pastures and water sources inexhaustible, not only to promote the benign cycle of grassland ecosystems, but also the protection of sustainable development of animal husbandry; Hani, Dai, Dong etc. rice-growing and other ethnic groups in south China developed the concept of forest ecosystems, which provides sufficient water and a friendly ecological environment for rice production under the forest-water-farm land model.

\subsection{The view of equality from revering life}

Due to the limitation of productivity level, ethnic minorities usually deify nature \& natural creatures. Worship for heaven \& earth is the most important content of worship of nature. Tibetans' ancient ideas believe that all species are from the same origin and lives are correlated; Uygurs view their existence as sustained by the Eternal Blue Sky, Tengri, the fertile Mother-Earth Spirit Eje, and a ruler who is regarded as the Holy Spirit of the Sky. Heaven, earth, the spirits of nature and the ancestors provide every need and protect all humans; Dai and Bulang in Xishuangbanna of Yunnan province both have the fine tradition of worship and protection of the "Dragon Mountain"; The Yi minority deify the trees around the village, while the Qiang and Bulang treat the forest as a god; The Dai believe that the elephants and the peacocks are auspicious things, people will not allow any harm to them; The Tokenism from North Shamanism regard bears, wolves, eagles etc. as their gods. All of these contribute to the protection of the ecological resources of mankind in an important way. Especially in animal protection, ethnic minorities have developed the ethical awareness of wild life conservation.

Civilization thrives while ecology does, and Civilization withers with ecology. The core value of the eco-culture is that 
man should live in harmony \& equality with nature, and all species should co-exist with renewable resources, which is fundamentally in consistency with the ecological ideologies of ethnic minorities. Man and other species are not divided into high and low social status, we are in one natural system, which is consistent with minorities' concept of "equality in awe of life". Different species in nature are bond to each other \& are dependent on each other, and they maintain balance and stability of the earth eco-systems. Distinction should not happen by over-development of other species, which reflects ecological ethics "the overall harmony of the natural". Nature evolved from inorganic to organic life and developed a natural cycle of regeneration of the eco-system from energy to the material, the view of "simple cycle of production" of ethnic minorities will help to maintain this cycle of regeneration.

Ecological crisis is the greatest of mankind's survival, and the crisis was mainly due to human misconduct when people's ethical culture has erred. Therefore, the ecological crisis is essentially an ethical crisis of faith and it is a cultural crisis. The history and social development of ethnic minorities is in fact the history of the relationship between ethnic minorities and the natural environment. Ethic minorities bound by their culture, norms, have constantly adjusted their behavior and the relationship between man and nature, protected the natural ecological environment, maintained national cohesion, and promoted harmonic sustainable development in the regions of ethnic minorities.

\section{Research on ecological civilization construction strategies in ethnic areas}

The basic contradiction of the eco-economic system is that of a growth-oriented economic system of unlimited demand for natural resources between ecosystems with limited stable supply of natural resources. On the one hand, the development demand of human activities on ecosystems are increasing; on the other hand, the supply of the overloaded ecosystem continues to decline, especially for the more vulnerable ethnic minorities' ecological areas, where economic development, social progress and ecological civilization face various pressures and challenges. In order to comprehensively building a harmonious society and sustainable economy and social development, ethnic minority areas should promote the construction of ecological civilization from multiple aspects.

\subsection{Inherit and promote eco-ethics from ethnic regions}

The rational factor in China's traditional eco- ethics in minorities is an intuitive and simple sentimental concept, without a comprehensive exposition on the relationship between man and nature. The integration of ecological ethics of minorities and the modern ethics is a rational choice for the reservation of ecology and the harmonious development in ethnic regions. The shared prosperity and a harmonious society of ecological civilization have to be ultimately achieved based upon the ecological ethics from minorities through the absorption of the theory of modern science to fit their specific situations. With the development of society, ethnic minorities have been unable to adapt to ecological ethics in pursuit of a modern society for the purpose of maximizing the economic benefits of large-scale material production activities. Therefore, the inheritance of traditional eco-ethics from minorities must be uplifted so that it is built on the basis of modern science.

\subsection{The cultivation of "ecological citizenship" awareness}

Ecological and environmental problems are essentially human survival and development issues and ecological civilization construction calls for "eco-citizenship." Through the promulgation of the ecological environment education, the whole nation's ecological awareness will be enhanced; the code of conduct in protection of the ecological environment will be established; and the concept of gradually establish a view of coordination of nature, a moderate and reasonable consumption and the sustainable development will be brought to light. "Civic awareness" is better over 1000 laws and regulations and the cultivation of "eco-citizens" is an essential requirement for the sound development of the ecological environment. The development of "sense of eco-citizens" is responsible for the "civic responsibility" in solving ecological problems in a fundamental way. Though fully understanding the rational factors in decision-making behavior of individual citizens and through legal, administrative, economic and other incentive-based measures, supplemented by a means of enforcement, combined with eco-ethics from ethnic minorities, an established code of conduct conscious citizens is the most effective, ever-lasting and prevention-over-restoration approach for ecological conservation.

\subsection{Improve related policies and regulations related to protect the ecology of the ethnic regions}

Rich ecological ethics are included in the life and production of ancient Mongolian, which leads to the prosperity of the Mongolian grassland in hundreds and thousands years. Basically the Mongolian grassland kept its primitive natural status until the middle $18^{\text {th }}$ century. As early as the dynasty of Genghis Khan, the destruction of ecological environment is listed as national prohibition, e.g. The hunting of immature animals are prohibited, trees were not allowed to be cut indiscriminately. "Those, who destroy the farming-land, will be punished ... the whole family will be executed if one forgot to extinguish fire and burn the grass land" was also a law at that time.

The system of ecology compensation funds should be improved in the minority areas, which makes the ecological compensation vertically from the government more specific and reasonable (The subject and object of the compensation, the standard and type of the compensation etc.). Especially the minority areas may fully take advantage of the "the law 
of autonomy of the ethnic regions" and the advantage of privilege of setting new laws of the government (especially the privilege of making changes accordingly). The national laws and regulations may be detailed, specific regulations may be added for execution to increase the operability and vigorously protect the construction of ecological civilization and the continuous development of economy and society. For example, in 2008, more than 1 million Yuan was provided through the regional \& county level finance of Ali to compensate the losses of the local people by wild animals. This is another example of "pay the bill" by government since the adoption of "Tibet Autonomous Region, Provisional Measures for Property Loss \& Personal Injuries by Prominent land Wildlife" by the government of the Tibet Autonomous Region in 2006.

\subsection{Developing the unique economy in circular model}

The value of the agriculture and industry is an economic value centered on the human being, while the ecological civilization requires to form an ecological value based upon the harmony of human and nature. The activities of human beings should be constrained within the limits of the natural ecological system, i.e. the economical construction and the ecological civilization should develop in harmony, obey the inner rule of the composite system of "society-ecology-economy".

The more national it is, the more international it is. With the development of economy and the society, people change from the consumption for existence to culture and unique consumption. To have advantages in the competition of the marketing economy, the minority areas must develop unique economy, cultivate and develop unique industry which reflects the nationality, the region and the ecology. The unique industry of the minority areas has broad commercial potential, e.g. The tobacco of Yunnan, the Gouqi of Ningxia, the oxen wool of Tibet, the raw paint in the west of Yunnan etc. Especially with the popularity of modern tourism to pursue uniqueness, knowledge and difference, the unique minority tourism has become the main industry in the regions of Yunnan, Tibet and Qinghai. The minority areas should combine local national characteristics - national situation, regional advantages - regional situation, market need commercial situation, to choose developing characteristic industry, explore how to use advanced techniques and skills to convert the potential advantages to real economical advantages and to realize the jump of the economy, choose the characteristic industry and those which may be able to co-existent, explore the model of unique circular economy development.

\section{References}

Baoli Bai. (2007). A study on the ecological ethics of the Chinese minorities (D), Beijing: Dissertation of the Central University of the Minorities, 3.

Hellstrand, S. (2006). A multi-criteria analysis of sustainability effects of increasing concentrate intensity in Swedish milk production 1989-1999. Environment, Development and Sustainability, 8(3), 351-373.

Jiancheng Chen. (2008). A study on the ecological civilization and the continuous development of the Chinese forest industry, Chinese hunan resources and the environment, 4, 139-142.

Kay, J. J. (1991). A nonequilibrium thermodynamic framework for discussing ecosystem integrity. Environmental Management, 15, 483-495.

Kfiberger, T., \& Mfinsson, B. (2001). Entropy and economic processes--Physics perspectives Economics, 36, 165-179.

Landner, L., Hellstrand, S., \& Mikaelsson, H. (2000a). Cadmium in phosphate fertilisers: Consequences of an eventual European standard limit. Stockholm: AF-Environmental Research Group Ltd. (AF-MFG).

Ming Jiang, Liqing Hou. (2008). The ecological culture of the woodland and the construction of the ecological utility area of Neimenggu, Ecological environment and protection, 1, 54-58.

OECD. (2001). Policies to enhance sustainable development. Meeting of the OECD Council at Ministerial level, 2001. Accessed March 29, 2008 from http://www.oecd.org/dataoecd/47/22/1869800.pdf.

Yi Zeng. (2008). The harmonic value of the minority ethics, The learning journal of the Guizhou Institute of Minorities (The version of philosophy and social study), 2, 73-76. 
Table 1. The status of ecological environment of ethnic regions

\begin{tabular}{|c|c|c|c|}
\hline $\begin{array}{l}\text { Ethnic } \\
\text { region }\end{array}$ & Ecological environment issues & Human factors & Natural factors \\
\hline Neimenggu & $\begin{array}{l}\text { Regression of woodland, desert of field, lost of } \\
\text { water and soil, industry pollution }\end{array}$ & $\begin{array}{l}\text { Overgrazing, extensive } \\
\text { management }\end{array}$ & drought \\
\hline Xinjiang & $\begin{array}{l}\text { Desert of field, salt and alkaline of field, lost of soil } \\
\text { and water, shortage of resources, industry pollution }\end{array}$ & $\begin{array}{l}\text { Over grazing, } \\
\text { indiscriminate logging, } \\
\text { over reclamation, } \\
\text { extensive mining }\end{array}$ & $\begin{array}{l}\text { Drought, desert } \\
\text { area }\end{array}$ \\
\hline Ningxia & $\begin{array}{l}\text { Sand of field, salt and alkaline of field, shortage of } \\
\text { water resources, industry pollution }\end{array}$ & $\begin{array}{l}\text { Overgrazing, extensive } \\
\text { management }\end{array}$ & $\begin{array}{l}\text { Drought in north } \\
\text { area, complicated } \\
\text { terrain in south }\end{array}$ \\
\hline Qinghai & $\begin{array}{l}\text { Sand of field, shortage of water resources, lost of } \\
\text { water and soil, shrink of woodland and forest, } \\
\text { decrease of multi-biology }\end{array}$ & $\begin{array}{l}\text { Overgrazing, } \\
\text { indiscriminate mining, } \\
\text { extensive management }\end{array}$ & $\begin{array}{l}\text { Alpine weather, } \\
\text { fragile ecological } \\
\text { system }\end{array}$ \\
\hline Guangxi & $\begin{array}{l}\text { Rock of field, decrease of multi-biology, lost of } \\
\text { water and soil, shrink of wetland and forest, industry } \\
\text { pollution }\end{array}$ & $\begin{array}{l}\text { Over logging, farming } \\
\text { on marine reclamation } \\
\text { land, extensive mining }\end{array}$ & $\begin{array}{l}\text { Fragmented } \\
\text { terrain, Karst } \\
\text { areas }\end{array}$ \\
\hline Tibet & $\begin{array}{l}\text { Regression of woodland, desert of field, lost of } \\
\text { water and soil, decrease of multi-biology, decrease } \\
\text { of coverage of plants }\end{array}$ & $\begin{array}{l}\text { Indiscriminate } \\
\text { development on wet } \\
\text { land, indiscriminate } \\
\text { mining/logging/hunting }\end{array}$ & $\begin{array}{l}\text { Cold-arid climate, } \\
\text { fragile ecology, } \\
\text { prone to natural } \\
\text { disasters }\end{array}$ \\
\hline Guizhou & $\begin{array}{l}\text { Rock of field, lost of water and soil, shrinkage of the } \\
\text { forest, severe environmental pollution, frequent } \\
\text { natural disasters }\end{array}$ & $\begin{array}{l}\text { Land reclamation } \\
\text { through deforestation, } \\
\text { cultivation on steep, } \\
\text { indiscriminate mining, } \\
\text { extensive management }\end{array}$ & $\begin{array}{l}\text { Fragmented } \\
\text { terrain, Karst } \\
\text { areas, prone to } \\
\text { natural disasters }\end{array}$ \\
\hline Yunnan & $\begin{array}{l}\text { The lost of water and soil, rock of the field, the } \\
\text { shrinkage of the forest, frequent disasters, industry } \\
\text { pollution, worse of the water quality }\end{array}$ & $\begin{array}{l}\text { Over logging, } \\
\text { extensive management }\end{array}$ & $\begin{array}{l}\text { Karst areas, prone } \\
\text { to natural } \\
\text { disasters }\end{array}$ \\
\hline
\end{tabular}

References: Wang Zhonghua (2005). Research on Economy Development and Ecology Protection in Ethnic Areas, 89. 